\section{'Norteña' Pecan}

\author{
Heriberto Aguilar Pérez
}

Sitio Experimental Zaragoza, INIFAP, Carr. Zaragoza-Cd. Acuña Km. 12, Zaragoza, Coahuila, México

Jesús Arreola Ávila ${ }^{1}$

Universidad Autónoma Chapingo, Unidad Regional Universitaria de Zonas Áridas, Bermejillo, Durango, México

\section{Emigdio Morales Olais and Eutimio Cuéllar Villarreal}

Sitio Experimental Zaragoza, INIFAP, Carr. Zaragoza-Cd. Acuña Km. 12, Zaragoza, Coahuila, México

\section{Ángel Lagarda Murrieta}

Departamento de Horticultura, Universidad Autónoma Agraria Antonio Narro, Unidad Laguna, Periférico Raúl López Sánchez, Torreón, Coahuila, México

\section{Héctor Tarango Rivero}

Campo Experimental Delicias, INIFAP, Carr. Rosales Km. 2 Delicias, Chihuahua, México

\section{Jesús Humberto Núñez Moreno \\ Campo Experimental Costa de Hermosillo, INIFAP, Blvd. Del Bosque No. 7. Esq. Paseo de la Pradera, Col. Valle Verde, Hermosillo, Sonora, México}

\section{Leonardo Lombardini}

Texas A\&M University, Department of Horticultural Sciences, College Station, TX 77843-2133

Additional index words. Carya illinoinensis, cultivar, selection, production, quality

\section{Origin}

Norteña is a new pecan cultivar originated as an open-pollinated seedling tree that was selected for its outstanding behavior from a native stand of trees collected near the Conchos River in the state of Chihuahua, Mexico. 'Norteña' has been evaluated as 'Selection 19-20' after being grafted on five seedling - trees planted at $10 \times$ $10 \mathrm{~m}$ distance in the 1980s at INIFAP's Experiment Station of Zaragoza Coahuila (lat. $28^{\circ} 29^{\prime} 30^{\prime \prime} \mathrm{N}$; long. $100^{\circ} 55^{\prime} 10^{\prime \prime} \mathrm{W}$ ). 'Norteña' has been registered in the Servicio Nacional de Inspección y Certificación de Semilla (SNICS) and, recently, it has been budded in commercial orchards in the states of Chihuahua, Coahuila, and Sonora, Mexico. Because of its low vivipary incidence and downy spot (Mycosphaerella caryigena) resistance, this cultivar constitutes an important resource for pecan growers located in wet

Received for publication 6 May 2015. Accepted for publication 9 June 2015.

This Project was funded by INIFAP and SAGARPA-SNICS-SINAREFI, Mexico.

${ }^{1}$ Corresponding author. E-mail: jgarreola@chapingo. uruza.edu.mx. regions where these problems are often.

\section{Description}

'Norteña' is protandrous with pollen shed and pistillate flower receptivity similar in timing to 'Western Schley' (Table 1). Trees are upright in growth habit and develop strong limb angles. Selective limb pruning (Worley, 1991) has been done in January after "off" years by eliminating one or two branches of $\approx 10-12 \mathrm{~cm}$ (five inches in diameter). Bud break of 'Norteña' begins around the third week of March, similar to what observed in 'Western Schley' (Table 1). In 2007, 2008, and 2009, 'Norteña' nuts matured on 22, 20, and 23 Sept., respectively, and they were ready to harvest $\approx 1$ week before 'Western Schley'. Yield data indicate that 'Norteña' is a good producer; in a 7-year period, it averaged $18.0 \mathrm{~kg}$ per tree (Table 2). Alternate bearing index $(I)$, as calculated according to Pearce and Doberšek-Urbanc (1967), was low (0.39), at least during this initial production period of the trees, which should be a successful result of good management and appropriate cultivar combination (Conner and Worley, 2000; Lagarda et al., 1998; Wood et al., 2003). Nut weight average across the 7-year period was $7.9 \mathrm{~g}$. Nuts shell out easily into full halves, the partition wall is thin, and the basal cleft is almost absent. Percentage kernel is always between $58.1 \%$ and $58.6 \%$ (data not shown). Kernels are cream to golden in color (Fig. 1) and have wide, non-trapping dorsal grooves and rounded dorsal ridges. Vivipary in 'Norteña averaged $2 \%$ in a 7 -year period, compared with $11 \%$ observed in western Schley (data not shown). This trend toward low vivipary supports the recommendation of using 'Norteña' in Nuevo Leon, Coahuila, Durango, and Sonora, Mexico, as well as other pecan growing regions where vivipary is common, and can reach values as high as $40 \%$. 'Norteña' has shown resistance to downy spot (Table 3 ) and could be a suitable cultivar for wet regions where other pecan cultivars are susceptible to this disease that reduces nut production and quality (Lagarda et al., 1998). Also, 'Norteña' has shown good tolerance to pecan scab (Fusicladium effusum Wint.) (Table 3).

\section{Availability}

Norteña was released in June 2010 and is currently being propagated in private nurseries to be planted in new orchards or topworked on older trees. Genetic material of 'Norteña' was deposited in the National Plant Germplasm bank at Tepatitlan, Jalisco, Mexico, where it will be available for future research and breeding of new cultivars.
Table 1. Dates of the main phenological stages for 'Norteña' compared with 'Western Schley' pecan observed at Zaragoza, Coahuila, Mexico in 2007, 2008, and 2009. 'Norteña' trees were grafted on open-pollinated rootstocks in 1987.

\begin{tabular}{|c|c|c|c|c|c|c|}
\hline \multirow[b]{3}{*}{ Phenological stage } & \multicolumn{6}{|c|}{ Date } \\
\hline & \multicolumn{3}{|c|}{ 'Norteña' } & \multicolumn{3}{|c|}{ 'Western Schley' } \\
\hline & 2007 & 2008 & 2009 & 2007 & 2008 & 2009 \\
\hline Bud break ${ }^{2}$ & 22 Mar. & 27 Mar. & 15 Mar. & 21 Mar. & 24 Mar. & 18 Mar. \\
\hline Shoot growth ${ }^{y}$ & 26 Mar. & 30 Mar. & 24 Mar. & 25 Mar. & 30 Mar. & $28 \mathrm{Mar}$. \\
\hline Initial pollen shed & 18 Apr. & 27 Apr. & 20 Apr. & 16 Apr. & 23 Apr. & 25 Apr. \\
\hline Final pollen shed & 1 May & 6 May & 2 May & 2 May & 7 May & 6 May \\
\hline Initial stigma receptivity & 21 Apr. & 25 Apr. & 20 Apr. & 19 Apr. & 20 Apr. & 15 Apr. \\
\hline Final stigma receptivity & 2 May & 10 May & 7 May & 5 May & 3 May & 1 May \\
\hline Fruit development ${ }^{\mathrm{x}}$ & 5 May & 15 May & 12 May & 7 May & 10 May & 11 May \\
\hline Water stage $^{\mathrm{w}}$ & 10 June & 13 June & 6 June & 12 June & 16 June & 9 June \\
\hline Shell hardening ${ }^{\mathrm{v}}$ & 28 July & 30 July & 27 July & 30 July & 29 July & 28 July \\
\hline Nut maturity $^{\mathrm{u}}$ & 22 Sept. & 20 Sept. & 23 Sept. & 30 Sept. & 27 Sept. & 29 Sept \\
\hline
\end{tabular}

${ }^{2}$ Leaf burst.

${ }^{y}$ Date corresponds to appearance of third node.

${ }^{\mathrm{x}, \mathrm{w}, \mathrm{v}}$ Date refers to first appearance of event.

"Recorded at $70 \%$ shuck split. 
Table 2. Yield (kg/tree) and alternate bearing index $(I)$ of pecan trees grafted in 1987 with 'Norteña' and 'Western Schley' grown at the Experiment Station of Zaragoza, Coahuila, Mexico.

\begin{tabular}{lccccccccc}
\hline & \multicolumn{7}{c}{ Yield kg/tree } \\
\cline { 2 - 9 } Cultivar & 2004 & 2005 & 2006 & 2007 & 2008 & 2009 & 2010 & Yearly mean \\
Norteña & $17.0 \mathrm{a}^{z}$ & $22.0 \mathrm{a}$ & $31.0 \mathrm{a}$ & $14.0 \mathrm{a}$ & $12.0 \mathrm{a}$ & $16.0 \mathrm{a}$ & $14.0 \mathrm{a}$ & 18.0 & 0.39 \\
Western Schley & $8.4 \mathrm{~b}$ & $20.0 \mathrm{a}$ & $13.0 \mathrm{a}$ & $12.0 \mathrm{a}$ & $9.3 \mathrm{a}$ & $13.0 \mathrm{a}$ & $7.2 \mathrm{~b}$ & 11.8 & 0.32 \\
\hline
\end{tabular}

${ }^{2}$ Means of five single-tree replications within columns followed by the same letter are not significantly different according to Duncan's multiple range test at $\alpha=0.05$.

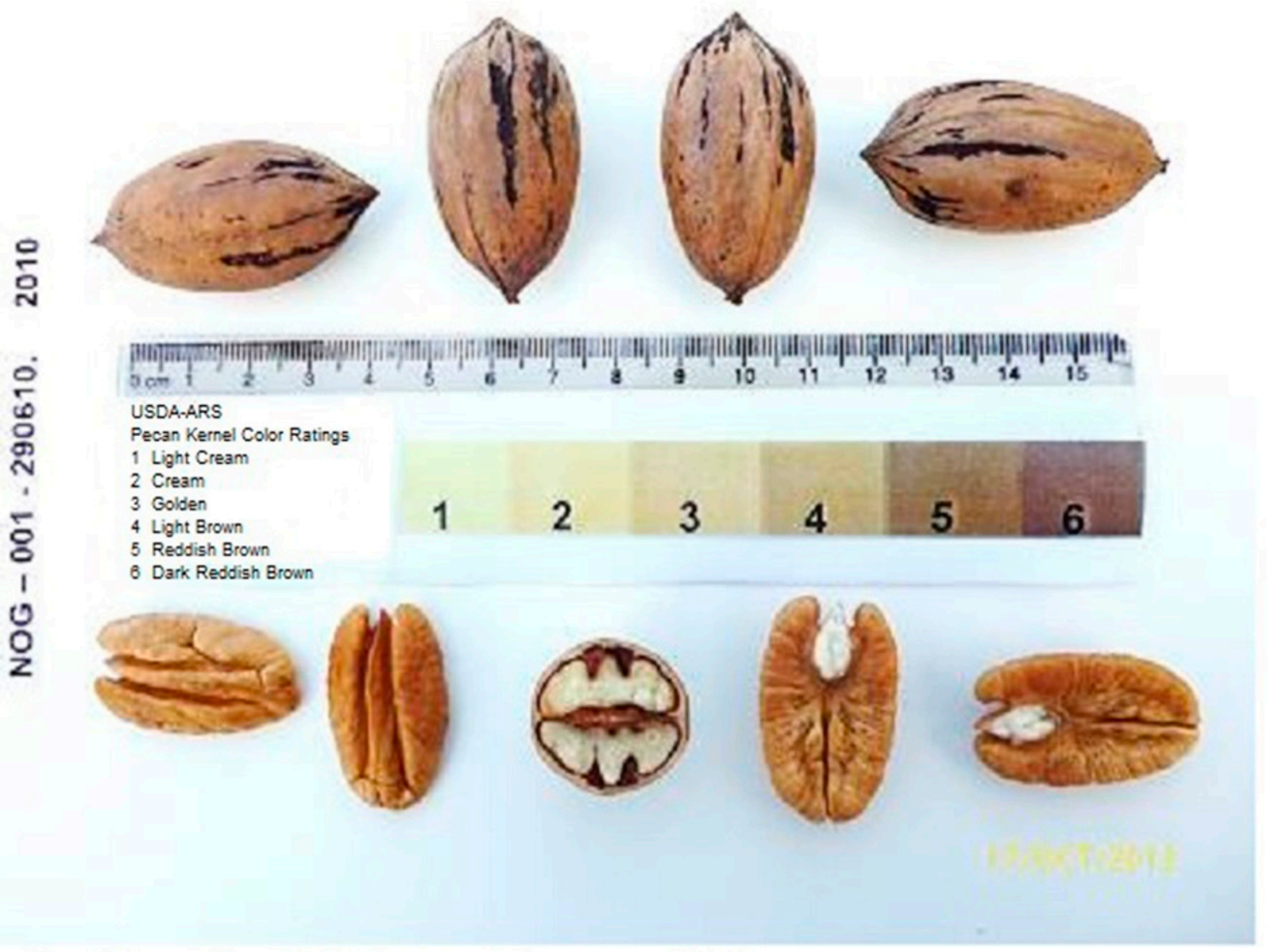

Fig. 1. Nuts and kernels of the 'Norteña' pecan. Scale is in centimeters.

Table 3. Leaf downy spot incidence and fruit scab ratings of 'Norteña' and 'Western Schley' pecan evaluated between 2007 and 2009 . Trees were grafted in 1987 and grown at the Experiment Station of Zaragoza, Coahuila, Mexico.

\begin{tabular}{|c|c|c|c|c|c|c|}
\hline \multirow[b]{2}{*}{ Cultivar } & \multicolumn{3}{|c|}{ Downy spot (number/leaf) z } & \multicolumn{3}{|c|}{ Scab index ${ }^{y}$} \\
\hline & 2007 & 2008 & 2009 & 2007 & 2008 & 2009 \\
\hline Western Schley & $\begin{array}{r}180 \mathrm{a} \\
* * *\end{array}$ & $\begin{array}{c}167 \mathrm{a} \\
* * *\end{array}$ & $\begin{array}{c}208 \mathrm{a} \\
* * *\end{array}$ & $\begin{array}{c}4.7 \mathrm{a} \\
*\end{array}$ & $\begin{array}{c}4.0 \mathrm{a} \\
*\end{array}$ & $\begin{array}{c}5.0 \mathrm{a} \\
*\end{array}$ \\
\hline
\end{tabular}

${ }^{\mathrm{z}}$ Number of spots per compound leaf. Values are means of four readings performed on each side of the tree canopy (N, S, E, and W) on five replicate trees.

${ }^{\mathrm{y}} 1=$ no scab, $2=$ trace- $10 \%, 3=11 \%$ to $25 \%, 4=26 \%$ to $50 \%, 5=51 \%$ to $100 \%$ according to grading scale for pecan nuts (Hunter and Roberts, 1978 ). Values are means of readings performed in 25 nuts per tree. Scab Index was obtained by averaging the products of each grade and nut number in that grade. Five trees were considered.

${ }^{\mathrm{x}}$ Means within column followed by the same letter are not significantly different according to Duncan's range test at $\alpha \leq 0.05$.

*,*** Significant at $P \leq 0.05$ or $\leq 0.001$, respectively.

\section{Literature Cited}

Conner, P.J. and R.E. Worley. 2000. Alternate bearing intensity of pecan cultivars. HortScience 35:1067-1069.

Hunter, R.E. and D.D. Roberts. 1978. A disease grading system for pecan scab. Pecan Qrtly. 12:3-6.

Lagarda, M.A., M.C. Medina, and A.J. Arreola. 1998. Productive performance of 14 pecan cultivars in the arid zone of the North of Mexico, p. 194-200. In: B. McCraw, E.H. Dean, and B.W. Wood (eds.). Pecan industry: Current situation and future challenges. U.S. Dept. Agr. Agr. Res. Serv.

Pearce, S.C. and S. Doberšek-Urbanc. 1967. The measurement of irregularity in growth and cropping. J. Hort. Sci. 42:295-305.
Wood, B.W., P.J. Conner, and R.A. Worley. 2003. Relationship of alternate bearing intensity in pecan to fruit and canopy characteristics. HortScience 38:361-366.

Worley, R.E. 1991. Selective limb pruning intensity influence mature pecan trees and nut characteristics. HortScience 26:126128. 